\title{
MOLECULAR MARKERS FOR THE DIAGNOSIS OF HIGH-RISK HUMAN PAPILLOMAVIRUS INFECTION AND TRIAGE OF HUMAN PAPILLOMAVIRUS-POSITIVE WOMEN
}

\author{
Kirvis Torres-Poveda ${ }^{1,2}$, Patricia Piña-Sánchez ${ }^{3}$, Verónica Vallejo-Ruiz $^{4}$, Marcela Lizano $^{5}$, \\ Aurelio Cruz-ValdeZ ${ }^{6}$, Paula JuÁrez-SÁnchez ${ }^{7}$, Jaime de la Garza-Salazar ${ }^{7}$, AND JoAQuín \\ MANZO-MERINO $8,9 *$ \\ ${ }^{1}$ Center for Research in Infectious Diseases, Instituto Nacional de Salud Pública, Cuernavaca, Mor., Mexico; \\ ${ }^{2}$ Consejo Nacional de Ciencia y Tecnología (CONACyT)-Instituto Nacional de Salud Pública, Cuernavaca, Mor.; \\ ${ }^{3}$ Unit for Medical Research in Oncological Diseases, Centro Médico Nacional Siglo XXI, Instituto Mexicano del Seguro \\ Social (IMSS), Mexico City; ${ }^{4}$ Centro de Investigación Biomédica de Oriente (CIBIOR), IMSS, Atlixco, Pue., Mexico; \\ 5 Unit of Biomedical Research in Cancer, Instituto Nacional de Cancerología-Instituto de Investigaciones Biomédicas, \\ Universidad Nacional Autónoma de México (UNAM), Mexico City; ${ }^{6}$ Population Health Research Center, Instituto \\ Nacional de Salud Pública, Cuernavaca, Mor.; ${ }^{7}$ Department of Clinical Research, Instituto Nacional de Cancerología, \\ Mexico City; ${ }^{8}$ Department of Basic Research, Instituto Nacional de Cancerología, Mexico City; ${ }^{9}$ CONACyT-Instituto \\ Nacional de Cancerología, Mexico City, Mexico
}

\begin{abstract}
Infection with high-risk human papillomavirus (HPV) increases the likelihood of developing cervical cancer (CC). A plethora of cellular processes is required to produce pre-malignant lesions, which in turn may become malignant if left untreated. Those changes are induced by viral oncoproteins, which represent an ideal target to identify the viral presence, or by some particularities of the host that ultimately promote the establishment of CC. This article describes the different methods used for HPV detection and quantification, as well as the current trend of secondary screening approaches to detect premalignant lesions and CC. In addition, we analyzed validated biomarkers and those under clinical investigation for the classification (triage) of women at risk of developing CC after an initial positive HPV test and that could be used as prognostic biomarkers for CC. The use of molecular biomarkers, together with the detection of HPV DNA sequences, provides a high impact diagnostic and prognostic tool in the detection of patients at increased risk of developing CC and also may guide their clinical management. In addition, some of those biomarkers could represent pharmacological targets for the future design of therapeutic approaches to CC treatment. (REV INVEST CLIN. 2020;72(4):198-212)
\end{abstract}

Key words: Human papillomavirus. Cervical neoplasm. Prevention. Diagnosis. Triage. Cytology. Biomarkers.

*Corresponding author:

Joaquín Manzo-Merino

E-mail: jmanzome@conacyt.mx
Received for publication: 20-02-2020

Approved for publication: 08-04-2020

DOI: $10.24875 / R I C .20000058$

0034-8376 / (c) 2020 Revista de Investigación Clínica. Published by Permanyer. This is an open access article under the CC BY-NC-ND license (http://creativecommons.org/licenses/by-nc-nd/4.0/). 


\section{INTRODUCTION}

The relationship between the presence of human papillomavirus (HPV) and cervical cancer (CC) is clearly established ${ }^{1}$. HPVs that infect the genital epithelium are classified according to their oncogenic potential as high-risk (HR) and low-risk (LR) HPVs. Among the HR types, $12 \mathrm{HPV}$ genotypes are classified as type I carcinogens, including HPV16, 18, 31, 33, 35, 39, 45, 51, $52,56,58$, and 59; as a probable carcinogen, HPV68; and as possible carcinogens, HPV26, 53, 66, 67, 70, 73 and $82^{2,3}$. Worldwide, the prevalence of HPV infection in women with no cervix abnormalities is $11-12 \%$, while the prevalence in Latin America is $16 \%{ }^{4}$. Agespecific HPV distribution exhibits a peak at young ages and a rebound at older ages in the Americas and Africa. The most prevalent HPV genotypes are HPV16 (3.2\%), HPV18 (1.4\%), HPV52 (0.9\%), HPV31 (0.8\%), and HPV $58(0.7 \%)^{5}$. Importantly, the two most up-todate previous studies based on large populations in Mexico have reported HR-HPV specific prevalence estimates between $11 \%$ and $13 \% 6,7$. A recent study determined the presence of HR-HPV in Mexican women from 20 different states, establishing prevalence of $24.78 \%$ of HR-HPV in Mexico, where types 16, 31, 51, and 18 were the most frequent, with $4.13 \%, 4.12 \%$, $3.39 \%$, and $1.7 \%$, respectively ${ }^{8}$.

The risk of developing premalignant lesions is associated with persistent infection with HR-HPV types, the most prevalent being types 16 and 18 . HPV 16 persistent infection is usually associated with faster progression to premalignant lesions of the cervix and invasive CC ${ }^{9}$. Nearly $73 \%$ of invasive CCs are associated with the HPV16 and 18 types, albeit more frequently with HPV16 (57\%), followed by HPV18 (16\%). This association has been reported in $70-76 \%$ of invasive CCs in different regions of the world ${ }^{10}$.

Estimates suggest that over $50 \%$ of young women after their first sexual encounter become infected with HPV as do more than $80 \%$ of women throughout their lives. However, in about $90 \%$, infections are spontaneously eliminated over a period ranging from 6 months to up to 3 years, while $10 \%$ remain persistently infected and $<1 \%$ will develop cancer, largely due to a failure in the immune response ${ }^{11,12}$.

In this article, we review the evidence on the methods for HPV detection and quantification, as well as validated biomarkers and those under clinical investigation for the classification (triage) of women at risk of developing CC after an initial positive HPV test.

A systematic literature search led by the population, intervention, control, and outcomes (PICO) question was conducted to identify articles covering HPV diagnosis, biomarkers for triage, and CC screening. From this question, a search in the MEDLINE database was performed through the PubMed database browser with the combination of the following terms: "HPV," "molecular marker," "diagnosis," "triage," "uterine cervical neoplasm," "cervical intraepithelial neoplasia (CIN)," and "CC." The search was limited to the studies published in the past 15 years to ensure the most updated collection of scientific evidence. The search was performed with the restriction of the language of full text to English.

The scope of computerized literature search was expanded according to the reference lists of retrieved articles. Original articles were screened manually by four independent reviewers (KTP, PPS, VVR, and JMM). If the full text of an article was not available online to perform the screening, we proceeded to contact the first author of the article by e-mail requesting a copy of their work to ensure that relevant studies were not lost.

The synthesis of the information was done considering the quality of the evidence through the GRADE system, and recommendations were formulated according to their strength of recommendation on the strategies that have been validated so far for the selection (triage) of the population at risk of developing premalignant cancer lesions and CC.

\section{CERVICAL CANCER SCREENING PROGRAMS BASED ON CYTOLOGY}

The programs for $\mathrm{CC}$ detection based on the analysis of cytological abnormalities with the Pap smear test have decreased the incidence of CC in developed countries and, in very few cases, in developing countries $^{13}$. Cervical cytology as a screening test allows the detection of cellular changes indicating the presence of CIN or cancer; however, it has limited sensitivity (50-84\%) and low reproducibility, since it depends on different factors that may affect the result, such 
as sample obtaining technique, adequate processing, and interpretation, which makes it necessary to repeat the tests frequently ${ }^{14,15}$. Further, the possibility exists of over-treating women with suspicious cytological abnormalities that may later be confirmed to be negative in the diagnostic process. This implies multiple gynecological visits when abnormal cytology is detected since they will be referred to colposcopy and biopsy procedures to confirm the diagnosis and initiate treatment. This represents a high cost for health systems, as well as complications that hinder the implementation and success of cytology-based screening in developing countries ${ }^{16}$. Different international guidelines recommend that screening for HPV should be included in CC screening to increase its sensitivity. Several studies have shown that sensitivity in the detection of premalignant lesions is increased when HPV detection is incorporated into cervical cytology 17,18 . However, subsequent studies showed that HR-HPV detection is another option for CC primary screening ${ }^{16,19}$.

Studies conducted in different regions of Mexico report that the prevalence of HPV increases with disease severity, ranging between $8 \%$ and $40 \%$ in normal cytology, to $100 \%$ in samples with CC ${ }^{20-23}$. HPV16, 18 , and 45 types are more common in invasive CC in Mexico ( $53 \%, 12 \%$, and $6 \%$, respectively), while in the cervix free of neoplastic abnormalities, HR HPV16, 18, and 33 genotypes are the most frequent (3.2\%, 1.9\%, and $1.8 \%$, respectively) ${ }^{24}$. This indicates that screening programs should pay special attention to the presence of HPV16 but also to HPV18 and HPV4525. Considering that the sensitivity for HPV molecular detection is high, the follow-up of women with HPV positivity should be guaranteed, because most infections are self-limiting and only cases of persistent HRHPV infections could have a role in the development of $\mathrm{CC}^{26}$. A strategy currently being discussed is the possibility of identifying and characterizing molecular biomarkers related to the risk of developing precursor lesions and cancer and that could be used to improve triage in cases at higher risk of developing CC.

\section{MOLECULAR DIAGNOSTIC METHODS FOR HPV DETECTION}

There is a wide variety of HPV detection methods. These methods vary in terms of their sensitivity and the number of viral genotypes they detect. Some detect viral DNA, while others are designed to detect E6/E7 oncogenes mRNAs. However, only clinically validated tests with high levels of reproducibility are recommended for screening and/or triage (Table 1).

\section{HR-HPV DNA DETECTION TESTS AS PRIMARY SCREENING FOR CERVICAL CANCER}

Among the secondary strategies for CC prevention, the $\mathrm{WHO}$ proposes three screening methods: conventional or liquid-based cytology, visual inspection with acetic acid (VIA), and HR-HPV molecular detection ${ }^{27}$. The HPV DNA detection test has recently started to replace cytology for CC primary screening in several countries. For instance, Australia was the first country to introduce primary HPV screening into its national program and, along with vaccination, recent studies predict that CC will significantly decrease, or even be eliminated in the coming decades ${ }^{28}$.

The HPV DNA detection test is clinically useful for secondary CC prevention, in the diagnosis of lowgrade cervical premalignant lesions and as a follow-up test to assess treatment effectiveness. The international consensus currently recommends three strategies for the primary screening of CC: (1) the visual inspection technique with $5 \%$ acetic acid or Lugol's iodine (VIA and VILI, respectively), particularly in areas where high-tech diagnostic and treatment methods are not available, and thus women can be treated in the same session, if necessary; (2) liquid-based or conventional cytology; and (3) HR HPV molecular test, particularly in developed countries with wellestablished screening systems, due to the high specificity of this technique and the experience and infrastructure existing in those areas $^{29}$.

The prevalence of HPV is high in young women; however, in most cases, they develop an effective immune response that eliminates the acute infection in a short period, and therefore, primary screening through HPV detection is not recommended in women younger than 30 years $^{30}$.

The risk for developing low or high-grade cervical lesions originating from cytological abnormalities increases with age ${ }^{31}$; therefore, HPV detection is recommended in women older than 30 years. However, 
Table 1. HPV detection tests

\begin{tabular}{|c|c|c|c|c|c|c|c|c|}
\hline Test & Manufacturer & $\begin{array}{l}\text { Detected } \\
\text { HPV } \\
\text { genotypes }\end{array}$ & $\begin{array}{l}\text { Target } \\
\text { molecule }\end{array}$ & Sensitivity & Specificity & $\begin{array}{l}\text { Detected } \\
\text { outcome }\end{array}$ & References & $\begin{array}{l}\text { Quality of } \\
\text { evidence } \\
\text { (GRADE) }\end{array}$ \\
\hline \multicolumn{9}{|c|}{ High-risk HPV DNA detection tests } \\
\hline \multicolumn{2}{|c|}{$\begin{array}{l}\text { Hybrid Capture }{ }^{\oplus} \text { QIAGEN } \\
2 \text { (HC2)* }\end{array}$} & $\begin{array}{l}\text { Viral } \\
\text { genome }\end{array}$ & $\begin{array}{l}13 \text { carcinogenic } \\
\text { genotypes }\end{array}$ & $97 \%$ & $85 \%$ & $\mathrm{CIN} 2+$ & 64 & High \\
\hline \multicolumn{2}{|c|}{${ }^{2} \mathrm{COBAS}^{\oplus} 4800 *$ Roche } & L1 & $\begin{array}{l}13 \text { carcinogenic } \\
\text { genotypes } \\
\text { and HPV 66; } \\
\text { genotyping for } \\
\text { HPV } 16 \text { and } 18\end{array}$ & $90 \%$ & $94 \%$ & $\mathrm{CIN} 2+$ & 65 & High \\
\hline \multicolumn{2}{|c|}{$\begin{array}{l}\text { BD ONCLARITY BD } \\
\text { HPV }\end{array}$} & E6/E7 & $\begin{array}{l}14 \text { genotypes. } \\
\text { It genotypes } \\
16,18 \text {, and } 45\end{array}$ & $95 \%$ & $87.7 \%$ & $\mathrm{CIN} 2$ & 66,67 & High \\
\hline${ }^{1} \mathrm{CareHPV}^{\mathrm{T} \mathrm{\wedge} \wedge}$ & QIAGEN & $\begin{array}{c}\text { Viral } \\
\text { genome }\end{array}$ & $\begin{array}{l}13 \text { carcinogenic } \\
\text { genotypes } \\
\text { and HPV } 66\end{array}$ & $90 \%$ & $84 \%$ & $\mathrm{CIN} 2+$ & 37 & High \\
\hline \multicolumn{2}{|l|}{$\begin{array}{l}\text { GP5*/GP6 + } \\
\text { PCR-EIA }\end{array}$} & $\mathrm{L} 1$ & $\begin{array}{l}13 \text { carcinogenic } \\
\text { genotypes } \\
\text { and HPV } 66\end{array}$ & $94 \%$ & $90 \%$ & $\mathrm{CIN} 2+$ & 33,34 & High \\
\hline $\begin{array}{l}\text { INFINITI }{ }^{\circledR} \\
\text { HPV-HR } \\
\text { QUAD }\end{array}$ & AutoGenomics & E1 & $\begin{array}{l}13 \text { carcinogenic } \\
\text { genotypes } \\
\text { and HPV } 66\end{array}$ & $97.30 \%$ & $90 \%$ & $\mathrm{CIN} 2$ & 68 & Moderate \\
\hline $\begin{array}{l}\text { Anyplex II } \\
\text { HPV HR }\end{array}$ & SeaGen INC & & 14 genotypes & $94-92 \%$ & $81 \%$ & $\begin{array}{l}\text { HSIL, } \\
\text { CIN2+ }\end{array}$ & 69 & Moderate \\
\hline $\begin{array}{l}\text { Cervista }{ }^{T M} \\
\text { HPV HR }\end{array}$ & Hologic & & 14 genotypes & $89 \%$ & $91 \%$ & $\mathrm{CIN} 2+$ & 70 & Moderate \\
\hline $\begin{array}{l}\text { RealTime } \\
\text { high risk }\end{array}$ & Abbot & L1 & $\begin{array}{l}13 \text { carcinogenic } \\
\text { genotypes } \\
\text { and HPV 66; } \\
\text { genotyping } \\
\text { for HPV } 16 \\
\text { and } 18\end{array}$ & $95 \%$ & $92 \%$ & $\mathrm{CIN} 2+$ & 71 & Moderate \\
\hline \multicolumn{9}{|c|}{ High-risk HPV RNA detection tests } \\
\hline APTIMA ${ }^{\oplus *}$ & GenProbe & $\begin{array}{l}\text { E6/E7 } \\
\text { mRNA }\end{array}$ & $\begin{array}{l}13 \text { carcinogenic } \\
\text { genotypes } \\
\text { and HPV } 66\end{array}$ & $\begin{array}{c}94.2 \% \\
87-98 \% \\
98 \% \\
90-100 \%\end{array}$ & $\begin{array}{c}94.5 \% \\
63-90 \% \\
55-60 \%\end{array}$ & $\begin{array}{c}\text { CIN2+ } \\
\text { ASCUS } \\
\text { CIN2/CIN3+ } \\
\text { LSIL } \\
\text { CIN2+/CIN3+ }\end{array}$ & 15,65 & High \\
\hline $\begin{array}{l}\text { PreTect } \\
\text { Proofer }\end{array}$ & NorChip & $\begin{array}{l}\text { E6/E7 } \\
\text { mRNA }\end{array}$ & $\begin{array}{l}\text { VPH } 16,18 \\
31,33 \text { and } 45\end{array}$ & $75-79 \%$ & $100 \%$ & $\mathrm{CIN} 2+$ & 37 & Moderate \\
\hline
\end{tabular}

${ }^{1}$ Recommended by WHO for low and middle-income countries.

${ }^{2}$ Approved for primary screening.

HPV: Human Papillomavirus. 13 carcinogenic genotypes include HPV 68. *FDA-approved tests. ^ Low-cost test validated in the rural setting. Modified from Luhn et al., $2013^{37}$.

the average onset of sexual activity in Mexico is at the age of $16^{32}$, and considering that HPV transformation processes can take $5-10$ years, there is a possibility that some young women, under 30 years, may develop premalignant lesions or cancer without falling into the group of women older than 30 in whom HPV detection is recommended.
Viral DNA detection test, as a primary screening tool with triage cytology, allows the recommended detection intervals for the follow-up of women to be prolonged, in adherence to national screening programs ${ }^{33}$. In addition, recent studies have provided evidence supporting the use of HPV molecular detection: (1) as a primary screening test, (2) for the diagnosis of 
Figure 1. Secondary prevention algorithm and CC model of care in Mexico. ASCUS: atypical squamous cells of undetermined importance; LISL: low-grade intraepithelial squamous lesion; ASC-H: atypical squamous cells; HISL: high-grade intraepithelial squamous lesion; AGC-NOS: atypical glandular cells not otherwise specified; AGC-NEO: atypical glandular cells suggestive of neoplasm.

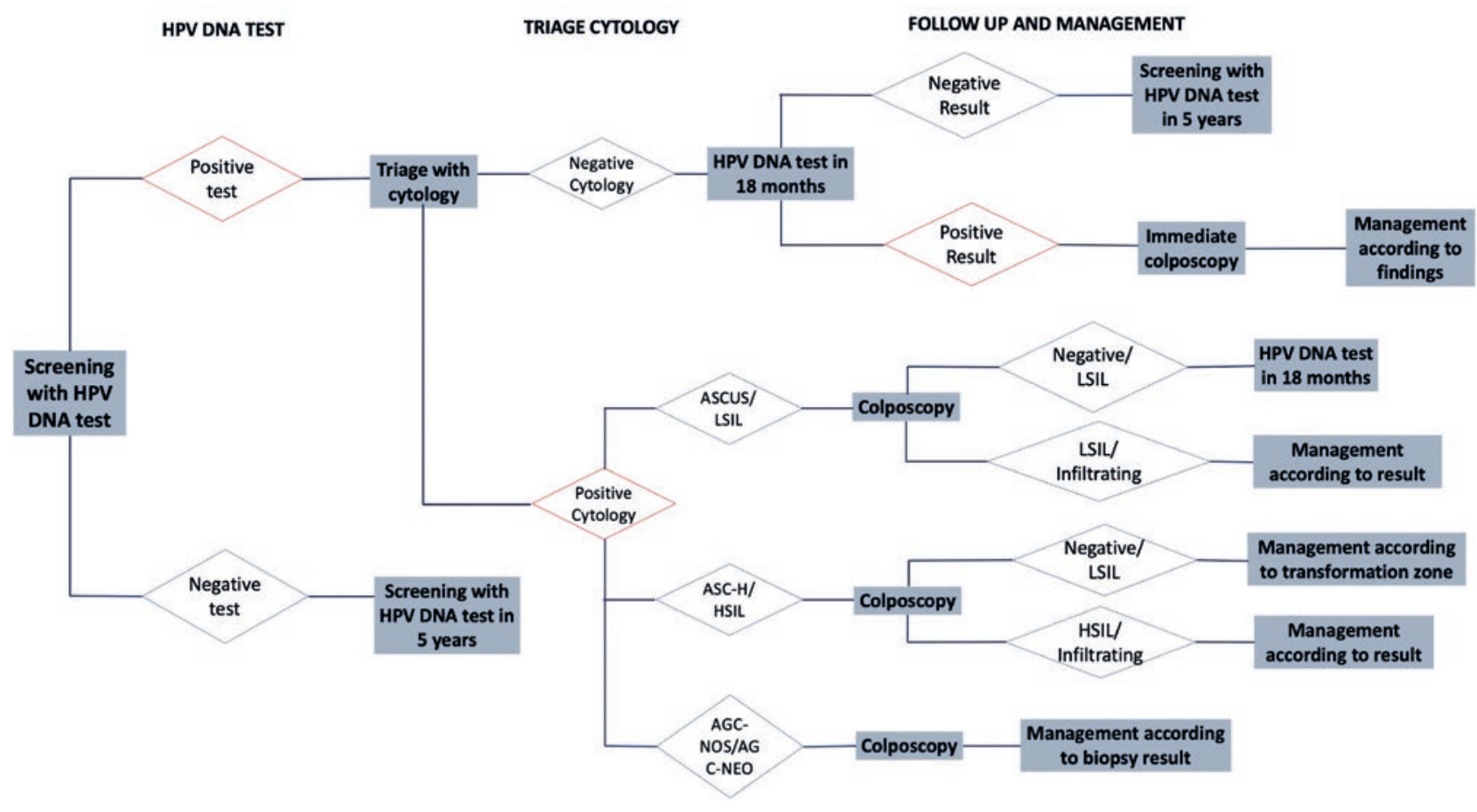

borderline cytology, (3) for follow-up after a positive primary test but without abnormal histology, and (4) as a test to assess recurrence after treatment or cure $^{34}$.

According to the NOM 014-SSA2-1994 Mexican standard "for the prevention, detection, diagnosis, treatment, control, and epidemiological surveillance of CC," modified in 2007, CC early detection tests should be performed in women between 25 and 64 years of age, an age range that will be modified in the following updated publication to 21 years as the age to begin cervical cytology testing. In public sector health facilities, these tests should be carried out free of charge without excluding any applicant women ${ }^{35}$. Primary health-care personnel provides cervical cytology and, according to institutional policies, biomolecular tests for HPV detection - Hybrid Capture (HC) and polymerase chain reaction (PCR) - can be used as a complement to cytology to improve detection sensitivity in women 35-64 years, an age range that will also be modified in the new update of the standard to 30-64 years.
The current specific action program for "Prevention and Control of Women's Cancer," which contains the CC Prevention and Control Program in Mexico, proposes primary screening with the HPV DNA test as a secondary prevention algorithm and model for the care of CC and triage with cytology and follow-up, as shown in figure 1.

The vaginal self-administered test is an alternative to the self-collected sample for HPV detection, especially to bring secondary CC screening closer to rural, indigenous, and urban marginalized women, who are at the highest risk of suffering from the disease. The implementation advantages are that these tests are easy to use, not so invasive, and less painful ${ }^{36}$.

\section{HPV DNA screening tests}

Different HPV molecular tests are commercially available (Table 1). Some detect a pool of genotypes and others, individual genotypes; however, not all have been clinically validated and only a few have been approved by the US Food and Drug Administration 
(FDA) ${ }^{37}$. HPV DNA screening tests can be divided into three subgroups: (i) tests that assess the presence of HPV carcinogenic types without providing individual genotyping information; (ii) assays that provide genotyping information for some HPV carcinogenic genotypes, mainly HPV 16 and 18 (either alone or in combination with a test for the presence of carcinogenic HPV); and (iii) assays that genotype simultaneously a large number of HPV types (Table 1). Since there is no clinical benefit to individual genotyping beyond the most frequent carcinogenic types (HPV 16 and HPV 18 ), only the two former tests are used in screening programs ${ }^{37}$.

The HPV DNA detection test most commonly used worldwide is HC2. It was approved in 1999 by the FDA for the triage of women with cytology reporting atypical squamous cells of undetermined significance (ASCUS) and to determine which women should be referred to colposcopy; in 2003, it was approved for primary screening in combination with cytology. Another widely used HPV DNA detection test is the GP5+/6+PCR enzyme immunoassay (EIA) test, with sensitivity and specificity similar to those of $\mathrm{HC}$. The tests proposed for CC screening programs must reach at least $90 \%$ sensitivity and $98 \%$ specificity, as shown for $\mathrm{HC} 2$ or $\mathrm{ElA}^{37}$. Validation of new screening tests should be performed comparing them with $\mathrm{HC} 2$ or GP5+/6+ PCR-EIA 38 .

A subset of HPV detection tests also provides genotyping information and can be divided into two subgroups: (i) concurrent genotyping tests, i.e., genotyping data are obtained at the same time as a qualitative result, such as the COBAS test, and (ii) subsequent genotyping tests, which provide genotyping data only if a sample is positive in the qualitative test, such as the Cervista HPV 16/18 (Hologic) test, approved by the FDA in 2009 for the selection of women with ASCUS cytology. The COBAS $4800 \mathrm{HPV}$ test, clinically validated and approved by the FDA in 2011, is currently recommended for screening women older than 21 years with ASCUS cytology, to determine the presence of HPV 16 and 18 in women older than 21 years with unclear Pap cytology, and together with cytology for primary detection in women above 30 years $^{19,37}$.

Systematic reviews of validation studies of HR HPV DNA detection tests, in randomized clinical trials and cohorts with a follow-up duration of 8 years or more, have reported reproducibility, relative sensitivity, and specificity results in comparison with $\mathrm{HC} 2$ test or PCR test using GP5+/6+primers. The COBAS 4800 HPV and Abbott RealTime High tests were systematically validated in three independent studies, with regard to the $\mathrm{HC} 2$ test for the detection of $\mathrm{CIN} 2+$, while the HPV PapilloCheck, BD Onclarity, HPV assay, and the HPV-Risk assay detection tests were validated in one study each. Other tests that partially meet the quality guidelines are the following: Cervista HR HPV test, GP5+/6+PCR-LMNX, a quantitative homemade reverse transcription-PCR that detects $\mathrm{E} 6 / \mathrm{E}^{37}$.

\section{MOLECULAR BIOMARKERS FOR THE TRIAGE OF WOMEN WITH POSITIVE HR-HPV DNA TESTS}

Due to the increase in primary screening with HPV DNA detection test, and their low positive predictive value, the issue to resolve is how to select women above the age of 30 with positive HR HPV, who are more likely to have or develop CC in the future, and their clinical management, given that nearly $73 \%$ of HPV-positive women above 30 years have negative cytology ${ }^{38}$. Therefore, biomarkers are required for the triage of women at risk of precursor lesions and CC after an initial positive HPV test.

A biomarker can be considered useful when the result of the test provides information for clinical management. In the case of HPV positive cases, management options include direct referral for treatment, referral to colposcopy to histologically confirm premalignant cervical lesions, increased surveillance through more intense screening, or release to routine screening. Management options should be chosen based on a woman's risk of having a cervical premalignant lesion or CC, as indicated by the results of screening and triage tests and other risk indicators such as age ${ }^{39}$.

Candidate biomarkers for this triage could be categorized into two groups, viral or cellular markers (Table 2). However, only a small subset of these proposed biomarkers has been approved for clinical application; others are still in pre-clinical and clinical trials ${ }^{39}$. 
Table 2. Biomarkers for cervical cancer screening and triage

\begin{tabular}{|c|c|c|c|c|}
\hline Type of biomarker & Test format & Application & $\begin{array}{l}\text { Quality of evidence/ } \\
\text { regulatory approval }\end{array}$ & $\begin{array}{l}\text { Test name/ } \\
\text { manufacturer reference }\end{array}$ \\
\hline \multicolumn{5}{|l|}{ HPV biomarkers } \\
\hline \multirow{15}{*}{$\begin{array}{l}\text { Oncogenic HPV DNA } \\
\text { detection (and } \\
\text { genotyping) }\end{array}$} & \multirow{15}{*}{$\begin{array}{l}\text { HPV genome } \\
\text { amplification } \\
\text { by PCR (e.g., } \\
\text { Linear Array }{ }^{\circledR} \text { ) }\end{array}$} & \multirow[t]{15}{*}{$\begin{array}{l}\text { Equivocal cytology } \\
\text { triage }\end{array}$} & \multirow{15}{*}{$\begin{array}{l}\text { Randomized clinical } \\
\text { studies and trials } \\
\text { in large populations. } \\
\text { Licensed tests for } \\
\text { use in the United } \\
\text { States and Europe }\end{array}$} & $\begin{array}{l}\text { Qiagen: Digene HC2, } \\
\text { careHPV'M }\end{array}$ \\
\hline & & & & QIAensemble ${ }^{\mathrm{TM} t}$ \\
\hline & & & & $\begin{array}{l}\text { Roche: Amplicor } \\
\text { Cobas }^{\oplus} 4800^{\dagger},\end{array}$ \\
\hline & & & & Linear Array ${ }^{\oplus \neq}$ \\
\hline & & & & Cervista $^{\circledR} \mathrm{HR}^{-\mathrm{HPV}^{\dagger}}$ \\
\hline & & & & $\mathrm{CLART}^{\oplus} \mathrm{HPV} \mathrm{H} \neq$ \\
\hline & & & & $\begin{array}{l}\text { Master Diagnóstica: } \\
\text { HPV Direct Flow Chip }\end{array}$ \\
\hline & & & & $\begin{array}{l}\text { AutoGenomics: } \\
\text { Infiniti }{ }^{\circledR} \text { HR-HPV }\end{array}$ \\
\hline & & & & QUAD $^{\ddagger}$ \\
\hline & & & & $\begin{array}{l}\text { BioRad: } \\
\text { HR-HPV Dx PCR }\end{array}$ \\
\hline & & & & $\begin{array}{l}\text { Innogenetics: } \\
\text { INNO-LiPA }{ }^{\text {TM‡ }}\end{array}$ \\
\hline & & & & $\begin{array}{l}\text { Multimetrix: } \\
\text { Multiplex HPV } \\
\text { Genotyping Kit }{ }^{\ddagger}\end{array}$ \\
\hline & & & & $\begin{array}{l}\text { Greiner: PapilloCheck }{ }^{\circledast} \\
\text { HPV Screening }\end{array}$ \\
\hline & & & & $\begin{array}{l}\text { Abbott: Real-Time } \\
\text { HR-HPV }{ }^{\oplus}\end{array}$ \\
\hline & & & & $\begin{array}{l}\text { Not commercialized: } \\
\text { GP 5+/6+ EIA } \neq \\
\text { Seegene: HPV } 28 \\
\text { Anyplex system }\end{array}$ \\
\hline \multirow[t]{5}{*}{$\begin{array}{l}\text { E6/E7 mRNA } \\
\text { detection }\end{array}$} & $\begin{array}{l}\text { Nucleic acid } \\
\text { sequence-based } \\
\text { amplification }\end{array}$ & $\begin{array}{l}\text { Adjunct to HPV-based } \\
\text { primary detection }\end{array}$ & $\begin{array}{l}\text { Published clinical } \\
\text { trials }\end{array}$ & $\begin{array}{r}\text { GenProbe: } \\
\text { Aptima }^{\circledR}\end{array}$ \\
\hline & $\begin{array}{l}\text { Transcription- } \\
\text { mediated } \\
\text { amplification }\end{array}$ & $\begin{array}{l}\text { Equivocal or slightly } \\
\text { abnormal cytology } \\
\text { triage }\end{array}$ & $\begin{array}{l}\text { Ongoing population- } \\
\text { based studies }\end{array}$ & $\begin{array}{l}\text { Norchip: PreTect }{ }^{\circledast} \\
\text { Proofer }^{\ddagger}\end{array}$ \\
\hline & \multirow[t]{3}{*}{$\begin{array}{l}\text { in situ } \\
\text { Hybridization }\end{array}$} & & & $\begin{array}{l}\text { BioMerieux: } \\
\text { NucliSENS EasyQ }{ }^{\circledR}\end{array}$ \\
\hline & & & & $\mathrm{HPV}^{\ddagger}$ \\
\hline & & & & $\begin{array}{l}\text { IncellDx: } \\
\text { HPV OncoTect }{ }^{\oplus \ddagger}\end{array}$ \\
\hline \multirow[t]{2}{*}{$\begin{array}{l}\text { HPV proteins } \\
\text { detection }\end{array}$} & $\begin{array}{l}\text { Histology and } \\
\text { cytology slides } \\
\text { immunostaining } \\
\text { (L1) }\end{array}$ & & $\begin{array}{l}\text { Some published } \\
\text { clinical trials }\end{array}$ & $\begin{array}{l}\text { Cytoimmun: } \\
\text { Cytoactiv }^{\circledR}\end{array}$ \\
\hline & Elisa (E6) & & & $\begin{array}{l}\text { ArborVita: } \\
\text { AVantage }^{\mathrm{TM}} \text { HPV E6 }\end{array}$ \\
\hline
\end{tabular}


Table 2. Biomarkers for cervical cancer screening and triage (continues from previous page)

\begin{tabular}{|c|c|c|c|c|}
\hline Type of biomarker & Test format & Application & $\begin{array}{l}\text { Quality of evidence/ } \\
\text { regulatory approval }\end{array}$ & $\begin{array}{l}\text { Test name/ } \\
\text { manufacturer reference }\end{array}$ \\
\hline \multicolumn{5}{|l|}{ Cellular biomarkers } \\
\hline \multirow[t]{2}{*}{$\begin{array}{l}\text { P16ink4a (also with } \\
\text { Ki-67 addition) }\end{array}$} & $\begin{array}{l}\text { Histology and } \\
\text { cytology slides } \\
\text { immunostaining }\end{array}$ & $\begin{array}{l}\text { Adjunct to HPV-based } \\
\text { primary detection }\end{array}$ & Published clinical trials & $\begin{array}{l}\text { mtm Laboratories: } \\
\text { CINtec }^{\circledast} \text { and }\end{array}$ \\
\hline & ELISA & $\begin{array}{l}\text { Equivocal or slightly } \\
\text { abnormal cytology } \\
\text { triage }\end{array}$ & $\begin{array}{l}\text { Ongoing population- } \\
\text { based studies }\end{array}$ & $\mathrm{CINtec}^{\circledR}$ PLUS \\
\hline \multirow[t]{2}{*}{ MCM2 and TOP2A } & \multirow{2}{*}{$\begin{array}{l}\text { Histology and } \\
\text { cytology slides } \\
\text { immunostaining }\end{array}$} & $\begin{array}{l}\text { Adjunct to HPV-based } \\
\text { primary detection }\end{array}$ & \multirow[t]{2}{*}{$\begin{array}{l}\text { Some published } \\
\text { clinical trials }\end{array}$} & \multirow[t]{2}{*}{$\begin{array}{l}\text { Becton Dickinson: } \\
\text { ProEx }{ }^{\top M} \mathrm{C}\end{array}$} \\
\hline & & $\begin{array}{l}\text { Equivocal or slightly } \\
\text { abnormal cytology } \\
\text { triage }\end{array}$ & & \\
\hline \multicolumn{5}{|l|}{ Methylation markers } \\
\hline \multirow{3}{*}{$\begin{array}{l}\text { SOX1, JAM3, } \\
\text { EPB41L3, C13orf18, } \\
\text { ANKRD18CP, } \\
\text { ZSCAN1, SOX1, } \\
\text { LMX1A, NKX6-1, } \\
\text { WT1, PAX1 RARß/ } \\
\text { TWIST/MGMT; } \\
\text { SOX1/HOXA11/ } \\
\text { CADM1; CCNA1/ } \\
\text { C13ORF18; CADM1/ } \\
\text { MAL; CDH13/DAPK/ } \\
\text { RAR } \beta / T W I S T 1 ; \\
\text { C13orf18/EPB41L3/ } \\
\text { JAM3; ANKRD18CP/ } \\
\text { C13orf18/JAM3; } \\
\text { SOX1/ ZSCAN1 }\end{array}$} & \multirow[t]{2}{*}{ Individual Markers } & $\begin{array}{l}\text { Adjunct to HPV-based } \\
\text { primary detection }\end{array}$ & \multirow[t]{3}{*}{$\begin{array}{l}\text { Published clinical } \\
\text { trials }\end{array}$} & \multirow[t]{2}{*}{39} \\
\hline & & $\begin{array}{l}\text { Equivocal or slightly } \\
\text { abnormal cytology } \\
\text { triage }\end{array}$ & & \\
\hline & Markers in panels & & & 54 \\
\hline
\end{tabular}

†'ncludes partial genotyping.

FGenotyping assay.

HPV: human papillomavirus; MCM2: minichromosome maintenance protein 2; TOP2A: topoisomerase II A.

\section{Viral biomarkers}

\section{Genotyping tests for HR-HPV}

Stratification of women with HPV 16 and 18 , responsible for approximately $70 \%$ of CC cases, allows the identification of women with the highest risk of developing $\mathrm{CIN} 3+$. Cohort studies have shown that the cumulative incidence of CIN3 among HPV16-positive women is higher ( $8.5 \%)$ in comparison with women positive to other HPV genotypes (3.1\%), underscoring the importance of colposcopy ${ }^{40}$.

The FDA-validated HR HPV genotyping tests include (a) concurrent HPV detection and genotyping tests such as COBAS HPV ${ }^{\circledR}$ (Roche) and real-time PCR (Abbott); and (b) the reflex HPV genotyping test such as
CERVISTA HPV 16/18 (Hologic). Among these, CO$\mathrm{BAS}^{\mathrm{HPV}}{ }^{\circledR}$ test has demonstrated excellent sensitivity and a positive predictive value similar to that of cytology (at the ASCUS level or worse), and higher in conjunction with cytology for the detection of CIN3 among HPV 16/18-positive women ${ }^{41}$.

Among the HPV full genotyping tests, several tests are based on PCR amplification of the L1 region and reverse hybridization with genotype-specific probes. This type includes the INNO-LiPA Genotyping Extra II test (Innogenetics) ${ }^{42}$, which allows the identification of 32 genotypes; Linear Array (Roche) identifies 37 viral genotypes; HPV Direct Flow CHIP (Master Diagnóstica) identifies 36 genotypes; and PapilloCheck ${ }^{\circledR}$ identifies 24 genotypes. Another test, Anyplex ${ }^{\mathrm{TM}}$ II HPV28, identifies 28 HPV genotypes by real-time PCR. These 
tests, in addition to the genotyping of high and LR HPV, identify the presence of coinfections (Table 1 ).

\section{Detection of E6 and E7 oncogenes messenger RNAs}

The quantification of E6/E7 mRNA levels has been proposed as a good candidate biomarker for HPVpositive patient triage, with clinical value for the detection of precursor lesions. In a population-based study, Rossi et al. identified that the triage strategy based on HPV16, 18, 45, 31, and 33 E6/E7 mRNA overexpression detection is better than cytology since $93 \%$ of samples with high-grade cytology were positive for E6/E7 $\mathrm{mRNA}^{43}$.

A meta-analysis showed the clinical application of HPV E6/E7 mRNA assessment to determine the risk of developing $\mathrm{CIN} 2+$ in women with slightly abnormal cytology. The expression levels of HPV E6/E7 mRNA in women with $\mathrm{CIN} 2+$ were significantly higher in comparison with those with normal cytology. The study indicated that women with HPV E6/E7 mRNA expression have a three-fold higher risk of developing $\mathrm{CIN} 2+$ than those who do not express it and, therefore, assessment of HPV E6/E7 mRNA expression may be a predictor of cervical lesion progression ${ }^{44}$.

The main RNA detection techniques for $\mathrm{E} 6$ and $\mathrm{E} 7$ viral oncogenes include the PreTect ${ }^{\circledR}$ HPV-Proofer and the APTIMA ${ }^{\oplus}$ tests. The PreTect ${ }^{\circledast}$ HPV-Proofer test allows the detection of five types of HR HPV $16,18,31,33,45$ with high sensitivity for the detection of high-grade squamous intraepithelial lesions (HSIL); however, it has not been approved by the FDA for use in CC screening ${ }^{37}$.

The APTIMA HPV assay detects E6/E7 mRNA of 14 HPV genotypes (13 carcinogenic genotypes plus HPV 66), but it does not distinguish between different types. In 2011, the FDA approved APTIMA for (i) classification of women older than 21 years with ASCUS cytology and (ii) detection of women aged 30 years or older in combination with cytology ${ }^{33}$. The results of several meta-analyses suggest that APTIMA has a higher sensitivity for the detection of $\mathrm{CIN}_{2}+$, but similar specificity to that shown by cytology. APTIMA has a similar sensitivity but higher specificity for both ASCUS classification or low grade squamous intraepithelial lesion (LSIL), in comparison with $\mathrm{HC}$, as well as in $\mathrm{CIN} 2+$ or $\mathrm{CIN} 3+$ primary detection ${ }^{37}$.
The mRNA detection by the APTIMA ${ }^{\circledast}$ test has higher specificity and sensitivity in comparison with DNA detection using the COBAS test. A study compared the performance of both methods in the detection of HSIL or more advanced lesions ( $\geq \mathrm{HSIL}$ ). Both methods showed high sensitivity (> 97\%) in biopsy-confirmed samples with $\geq$ HSIL. The COBAS test showed a higher rate of positive testing in the diagnosis of benign lesions ( $84 \%$ vs. $51 \%$ ) and LSIL ( $89 \%$ vs. $63 \%$ ) in comparison with the APTIMA test. In addition, APTIMA showed higher specificity for $\geq \mathrm{HSIL}$ than COBAS ( $41 \%$ vs. $13 \%$ ). Overall, APTIMA showed better detection, compared to COBAS, of biopsy-confirmed $\geq$ HSIL, with a superior predictive value ( $25 \%$ vs. $16 \%$ ) and higher accuracy (50\% vs. $26 \%)^{45}$.

\section{Tests for the detection of HR-HPV proteins}

OncoE6 and Cytoactiv are commercially available tests aimed to detect protein levels of E6/E7 and L1, respectively. Preliminary results of OncoE6 clinical validation indicate that it has higher specificity than the HC test (98.9\% vs. $86.8 \%$, respectively), but lower sensitivity ( $67.3 \%$ vs. $98.0 \%$, respectively) for the detection of $\mathrm{CIN} 3+{ }^{37}$.

The loss of L1 expression, which is the predominant capsid protein, has also been proposed as a marker of premalignant lesions since its expression depends on viral genome integrity. During HPV-induced carcinogenesis, the viral genome breaks down as a result of integration into the cell genome, resulting in $\mathrm{E} 6$ and E7 overexpression with the consequent loss of $L 1^{26,46}$. Although there is a commercially available test to detect the presence of L1 of several HPV types (Cytoactiv and (ytoimmun diagnostics), the clinical utility of this test has not yet been determined ${ }^{37}$.

\section{Cellular biomarkers}

\section{Markers associated with HPV-induced cell cycle dysregulation}

\section{P16INK4A}

A widely studied biomarker in HPV-induced cancer types is P16INK4A, a cyclin-dependent kinase inhibitor 
protein whose main action is to act as a proliferation inhibitor. It is overexpressed in cancerous and precancerous cervical tissue, resulting from an E7-mediated $\mathrm{Rb}$ pathway inhibition compensatory mechanism ${ }^{47}$. P16INK4A cellular accumulation can be detected by immunohistochemical staining of histological sections and cytological smear. The available test for P16INK4A detection commercially known as CINtec histology was FDA approved in 2017.

\section{$K 1-67$}

$\mathrm{Ki}-67$ protein is a proliferation marker that is overexpressed in the presence of the HPV E7 oncoprotein. Under normal conditions, p16 (tumor suppression protein) and Ki-67 (a proliferation marker) overexpression are mutually exclusive, but the detection of simultaneous overexpression by dual immunostaining identifies cells with a dysregulated cell cycle. In the case of HPV-positive women with negative cytology, p16/Ki-67 dual staining has a sensitivity of $97.2 \%$ and a specificity of $60 \%$ to detect $\mathrm{CIN} 3+$, with a decrease in referrals to colposcopy of $50 \%$. There is a dual staining test for these two proteins, CINtec PLUS Cytology ${ }^{48}$.

Specifically, the increase in the staining index using the monoclonal antibody (MIB-1) for Ki-67 detection is related to the progression of neoplastic lesions ( $8.38 \%$ in $\mathrm{CIN} 1,15.6 \%$ in $\mathrm{CIN} 2$, and $29.8 \%$ in CIN3) into squamous-cell carcinoma. Even the differentiation grade was associated with the staining index (51.6\% in well-differentiated carcinoma, $64.9 \%$ for moderately differentiated carcinoma, and $83.7 \%$ for poorly differentiated carcinoma). These results indicate that this protein may be an indicator of the potential for malignancy ${ }^{49}$.

\section{Aberrant phase $S$ induction markers}

HPV oncogene-mediated cell cycle activation during the cell transformation process is characterized by an aberrant induction of the $S$ phase. An assay that detects two proteins, topoisomerase IIA (TOP2A) and minichromosome maintenance protein 2 (MCM2), involved in aberrant induction of the $\mathrm{S}$ phase, is commercially available (ProEx ${ }^{\mathrm{TM}} \mathrm{C}$, Becton Dickinson). So far, some clinical trials with a limited sample size have shown that it has a sensitivity varying between 0.67 and 0.99 and a specificity ranging between 0.61 and $0.85^{39}$.

MCM5 protein expression has been proposed as a marker of cell proliferation since the levels of this protein increase in the $\mathrm{G} 1$ phase of the cell cycle and reach its peak expression in the $S$ phase. A study assessed MCM5 and P16INK4A expression in CIN and $C C$, showing that the expression of both MCM5 and P16INK4A gradually increases from normal cervical epithelium, through the different grades of $\mathrm{CIN}$ and to CC, with significantly higher expression in CC in comparison with normal cervical epithelium and $\mathrm{CIN}$ (1-3 ratio). These results show that both MCM5 and p16 are good indicators of the presence of early cervical intraepithelial lesions and also enable the distinction between $\mathrm{CIN}$ and $\mathrm{CC}^{50}$.

The molecules induced by several HR-HPVs involved in the replication, transcription and DNA repair, cell cycle or the process of metastasis are usually assessed by immunohistochemistry, but this is a morphological technique that has high inter-observer variation, and quantification is difficult to reproduce $^{51}$. Therefore, the detection of other biomarkers like mRNA is a less subjective strategy than immunohistochemical analysis. A study determined the viability of the detection of six mRNA biomarkers in liquid-based cytology samples and assessed their usefulness in the identification of patients with HSIL. The evaluated biomarkers included P16INK4A, BIRC5, metalloproteinase 9 (MMP9), TOP2A, MCM5, and MKi67 (MKI67). The expression of all markers, except for MCM5, showed significant differences according to the diagnosis (P16INK4A, BIRC5, MMP9, TOP2A, and MK167). Expression was higher in HSIL samples than in samples that were negative for the p16 ${ }^{\text {INK4a }}$, BIRC5, MMP9, TOP2A, and MKI67 markers, and in LSIL samples for the BIRC5, MMP9, TOP2A, and MKI67 markers. The biomarker with the highest sensitivity was TOP2A and the most specific was P16INK4A (Table 2). The combination of TOP2A and P16INK4A showed a sensitivity of $96 \%$ and a specificity of $71 \%$. The results of this study demonstrate that the assessment of mRNA expression in liquid-based cytological samples is feasible and that it can be used for the detection of HSIL, with TOP2A and P16INK4A being a combination with adequate sensitivity and specificity ${ }^{52}$. 


\section{Other biomarkers in the triage validation process}

Other cellular markers, such as cytokeratin $\mathrm{CK} 13$ and CK14, MCM5, cell division control protein 6, survivin, and carcinoembryonic antigen, have been assessed at several stages of tumor development. Most validation assays have shown a lack of consistency in the determination of cut-off points and limited sample sizes $^{39}$.

Other markers in early phases of discovery and validation are methylation markers, which are currently in the phase of validation for their potential use in clinical diagnosis. In the future, systemic markers, including genetic susceptibility markers, will also be available for validation as CC prognostic biomarkers.

\section{Methylation markers}

Methylation of the promoter region of specific genes, like tumor suppressor genes, has been associated to the development of cancer. Methylation of the CpG sites within the genome occurs at different levels during carcinogenesis. While tumors are often hypomethylated in repetitive DNA regions as long interspersed nuclear elements, the promoter regions of tumor suppressor genes can become hypermethylated, leading to a decrease in their expression ${ }^{53}$.

DNA methylation is a stable analyte that can be detected in biological samples, and changes in the methylation patterns that occur early in carcinogenesis are often retained in invasive tumors; this could be a potentially useful biomarker in clinical practice ${ }^{39}$.

Differentially methylated candidate genes in CC, identified by methylation profiles in cell lines derived from this neoplasm and normal cervical tissue, have been proposed as possible CC screening and prognostic biomarkers. Thus far, genes that show different levels of methylation have been reported when comparing cases of CC with normal tissue (Table 2). Some studies have demonstrated that the frequency of candidate genes' DNA methylation increases with premalignant cervical lesion increasing severity, suggesting that these changes occur early during transformation and are a potential source of biomarkers for CC early detection ${ }^{39}$.
A recent study evaluated the diagnostic potential of six methylated genes (JAM3, EPB41L3, C13orf18, ANKRD18CP, ZSCAN1, and SOX1) organized in three marker panels, in a cohort with HR-HPV positive detection. All six methylated genes showed an association with the histopathological report in the HR-HPVpositive cohorts and high sensitivity and specificity for the detection of $\mathrm{CIN}_{2}+$ and $\mathrm{CIN}_{3}+$. The sensitivity for CIN2+ was higher with the C13orf18/EPB41L3/JAM3 methylation panel in comparison with the other two panels ( $80 \%$ vs. $60 \%$ [ANKRD18CP/ C13orf18/JAM3] and 63\% [SOX1/ZSCAN1]). For $\mathrm{CIN} 3+$, all three assessed methylation panels showed comparable sensitivity within a range of $68-95 \%$. The specificity of the SOX1/ZSCAN1 panel ( $84 \%$ ) was considerably higher in comparison with ANKRD18CP/ C13orf18/JAM3 (68\%) and C13orf18/EPB41L3/ JAM3 (66\%). In addition, a high negative predictive value (NPV) was reported for $\mathrm{CIN} 2+$ and $\mathrm{CIN} 3+$ with all three methylation panels $(91-95 \%$ and $96-99 \%$, respectively), while positive predictive value (PPV) ranged from $25 \%$ to $40 \%$ for CIN2+ and 15 to $27 \%$ for $\mathrm{CIN} 3+{ }^{54}$. Thus, this study proposes these methylation markers as triage tests in screening programs based on the presence of HR-HPV, or in case of abnormal cytology tests.

Lorincz et al. proposed a methylation test of the EPB41L3 gene and HPV late region methylation ${ }^{55}$. In turn, Clark et al. proposed the methylation status of SOX1, DCC, and EPB41L3 methylation as possible markers for precursor lesions and CC detection ${ }^{56}$.

\section{Proteomic markers}

Most of the proteomic studies in CC have focused on comparing serum samples from patients with $\mathrm{CC}$ and healthy subjects to identify possible markers for this cancer. With the serum MALDI-TOF MS method, more than one protein marker can be identified. A study conducted with a serum of 165 patients identified three protein peaks that showed a significant difference between cancer patients and healthy volunteers; the molecular weights were $3974 \mathrm{Da}, 4175 \mathrm{Da}$, and $5906 \mathrm{Da}$. Validation data showed a sensitivity of this proteomic profile of $87.5 \%$ and a specificity of $90 \%$ for the detection of $\mathrm{CC}^{57}$.

However, most proteomic studies involve a low number of samples, few have studied precancerous 
lesions, and any differentially expressed protein still requires validation in more extensive studies. The use of new methods such as MALDI-TOF-MS could facilitate the discovery of different proteins related to the disease, to be used as possible biomarkers.

\section{miRNAs}

MicroRNAs (miRNAs) negatively regulate gene expression by binding to mRNA and prevent its translation. Abnormalities in miRNA expression patterns have been observed in several tumors and these changes have been suggested to be of prognostic value in various types of cancer ${ }^{58}$.

Studies in CC tumors and cancer-derived cell lines have identified up-regulated miRNAs (miR-21, miR-127, and miR-199a) and others with decreased expression (miR-143, miR214, miR-218, and miR-34a) in comparison with normal tissue. Expression changes in miRNAs have been observed in early precancerous lesions, so they could act as potential biomarkers for the early detection of $\mathrm{CC}^{38}$. Furthermore, altered miRNA profiles in $\mathrm{CC}$ are associated with treatment response, underscoring the usefulness of these molecules not only in the diagnosis but also in the prognosis of the disease ${ }^{59}$.

\section{Antibody profiles as cervical cancer biomarkers}

\section{Detection of antibodies against viral proteins}

HPV16 E7 oncoprotein is processed and presented to T lymphocytes, resulting in the production of antibodies against this oncoprotein that has been found to be elevated in serum, allowing for their detection and quantification. In addition, E7 continued expression is required for the maintenance of the malignant phenotype in HPV-induced neoplasms. Therefore, circulating levels of HPV16 E7 antibody could serve as a serum biomarker to detect HPV-associated cancers ${ }^{60}$. For this purpose, clinical validation of an immunoassay platform combined with a microfluidic filter for the detection of antibodies against the HPV E7 protein has been completed. The results showed a sensitivity of $94 \%$ and a specificity of $85 \%$. This detection method allows the quantification of antibodies against HPV16 E7 and the identification of groups at high risk of developing HPV-related cancer.

\section{Detection of antibodies against cellular proteins}

In CC, increased expression of survivin, a protein encoded by the baculoviral inhibitor of apoptosis protein repeat-containing protein five isoform 2 (BIRC5) gene and MYC (a protein product of the Myc protooncogene) have been reported. A study of 107 patients diagnosed with CC and 130 control women, analyzed circulating immunoglobulin $\mathrm{G}(\lg \mathrm{G})$ antibodies directed against BIRC5 and MYC, using an enzyme-linked immunosorbent assay (ELISA). The study showed significant differences in the levels of anti-BIRC5 IgG and anti-MYC IgG between the patient group and the control group. The anti-BIRC5 IgG test showed a sensitivity of $23.4 \%$ and a specificity of $90 \%$, while the anti-MYC IgG test obtained a sensitivity of $9.4 \%$ and a specificity of $90.6 \%$. Although highly sensitive tests are required to detect CC-associated antigens, these results suggest that anti-BIRC5 IgG may be a biomarker for the early diagnosis of this type of cancer ${ }^{61}$.

Not only can the P16INK4A protein and mRNA levels be assessed by immunohistochemistry or by quantitative PCR, respectively, but also considering its high expression in cancerous tissues, the production of antibodies against this protein can be related to the presence of a cancerous lesion, so the evaluation of this antibody is a potential analyte for cancer determination. A study assessed the levels of autoantibodies against circulating P16INK4A by ELISA in 141 patients with CC, 133 patients with benign cervical tumors and 153 controls. Anti-P16INK4A antibody levels were higher in the group of patients with malignant tumors than in the control group and in the group with benign tumors. Patients with stage I CC had higher levels of antibodies against P16INK4A, with a sensitivity of $20.3 \%$ and specificity above $90 \%$. These results indicate that the levels of circulating autoantibodies directed against $\mathrm{p} 16$ may be a potential biomarker with early prognostic value in $\mathrm{CC}^{62}$.

Forkhead transcription factor 3 (FOXP3) is a transcription factor whose expression levels have been linked to carcinogenesis and tumor development. FOXP3 is a specific marker of regulatory $T$ cells (Tregs) and is involved in their activation and functional regulation, in addition to being essential in autoimmune homeostasis dynamic regulation. A study 
assessed anti-FOXP3 IgG antibody levels by ELISA in 141 patients with CC, in 133 patients with benign cervical tumors and in 148 controls $^{63}$. The levels of anti-FOXP3 IgG were significantly higher in the group of patients with CC in comparison with the control group and the benign tumor group, and they were also higher in the benign tumor group compared to the control group. These results indicate that anti-FOXP3 antibodies can be markers of cervical premalignant lesion progression to CC. However, further studies are required to assess the sensitivity of the diagnostic test.

\section{CONCLUSION}

The use of molecular biomarkers together with HRHPV detection provides a diagnostic tool with important implications for clinical management by detecting patients at high risk of cervical premalignant lesions and CC.

\section{RECOMMENDATIONS}

1. HPV DNA detection tests are highly reproducible and have been clinically validated for primary screening of women above 30 years of age (Table 1 ), which provides great safety for the management of HPV-negative women, by allowing to prolong the screening interval. Quality of evidence: (GRADE) High. Strength of recommendation: Strong in favor of its use.

2. Implementation of HR HPV DNA molecular detection is a strategy that allows the selection (triage) of the population at risk of developing premalignant cancer lesions. Quality of evidence: (GRADE) High. Strength of recommendation: Strong in favor of its use.

3. Follow-up and treatment of HPV-positive women should be guaranteed. Quality of evidence: (GRADE) High. Strength of recommendation: Strong in favor of its use.

4. The use of viral and cellular biomarkers (E6/E7 [APTIMA] and Ki67 and P16INK4A [CINTec plus], respectively) could improve the triage of HR-HPVpositive women as well as risk stratification in the development of cervical premalignant lesions in the clinical setting and initiation of adequate therapeutic management; this would decrease costs resulting from treatment in advanced stages. Quality of evidence: (GRADE) Moderate. Strength of recommendation: Strong in favor of its use.

5. Quality control of the screening program processes is required. There is the standard that should be followed; however, a definition of scientifically based clinical algorithms in the Mexican context is required. Quality of evidence: (GRADE) High. Strength of recommendation: Weak in favor of its use.

6. Increase of effective coverage of secondary prevention program. Quality of evidence: (GRADE) High. Strength of recommendation: Strong in favor of its use.

7. Epidemiological surveillance is imperative in $\mathrm{CC}$ and precursor lesions to assess the impact of the screening program at the national level. Quality of evidence: (GRADE) High. Strength of recommendation: Strong in favor of its use.

8. Although new cell methylation biomarkers, miRNA levels, as well as protein analytes have been proposed, they must be validated in clinical trials to determine their impact in terms of diagnostic and prognostic value in CC. In addition, the resources for their implementation should be considered. Quality of evidence: (GRADE) Low. Strength of recommendation: Weak in favor of its use.

\section{REFERENCES}

1. Hausen HZ. Papillomaviruses causing cancer: evasion from hostcell control in early events in carcinogenesis. J Natl Cancer Inst. 2000;92:690-8.

2. Munoz N, Bosch FX, de Sanjose S, Herrero R, Castellsague X, Shah KV, et al. Epidemiologic classification of human papillomavirus types associated with cervical cancer. $N$ Engl J Med. 2003;348:518-27.

3. World Health Organization. Human Papillomaviruses. IARC Monogr Eval Carcinog risks to Humans. Vol. 90. Lyon, France: World Health Organization; 2007

4. Forman D, de Martel C, Lacey CJ, Soerjomataram I, Lortet-Tieulent J, Bruni L, et al. Global burden of human papillomavirus and related diseases. Vaccine. 2012;30:F12-23.

5. Bruni L, Diaz M, Castellsagué X, Ferrer E, Bosch FX, de Sanjosé $S$. Cervical human papillomavirus prevalence in 5 continents: meta-analysis of 1 million women with normal cytological findings. J Infect Dis. 2010;202:1789-99.

6. Rudolph SE, Lorincz A, Wheeler CM, Gravitt P, Lazcano-Ponce E Torres-lbarra L, et al. Population-based prevalence of cervical 
infection with human papillomavirus genotypes 16 and 18 and other high risk types in Tlaxcala, Mexico. BMC Infect Dis. 2016;16:461.

7. Torres-Poveda K, Ruiz-Fraga I, Madrid-Marina V, Chavez M, Richardson V. High risk HPV infection prevalence and associated cofactors: a population-based study in female ISSSTE beneficiaries attending the HPV screening and early detection of cervical cancer program. BMC Cancer. 2019;19:1205

8. Campos-Romero A, Anderson KS, Longatto-Filho A, Esparza MA, Moran-Portela DJ, Castro-Menendez JA, et al. The burden of 14 $\mathrm{hr}-\mathrm{HPV}$ genotypes in women attending routine cervical cancer screening in 20 states of Mexico: a cross-sectional study. Sci Rep. 2019;9:10094.

9. de Sanjose S, Brotons M, Pavon MA. The natural history of human papillomavirus infection. Best Pract Res Clin Obstet Gynaecol. 2018;47:2-13.

10. Li N, Franceschi S, Howell-Jones R, Snijders PJ, Clifford GM. Human papillomavirus type distribution in 30,848 invasive cervical cancers worldwide: variation by geographical region, histological type and year of publication. Int J Cancer. 2011; 128:927-35

11. Sasagawa T, Takagi H, Makinoda S. Immune responses against human papillomavirus (HPV) infection and evasion of host defense in cervical cancer. J Infect Chemother. 2012;18:807-15.

12. Skinner SR, Wheeler CM, Romanowski B, Castellsague X, Lazcano-Ponce E, Del Rosario-Raymundo MR, et al. Progression of HPV infection to detectable cervical lesions or clearance in adult women: analysis of the control arm of the Viviane study. Int J Cancer. 2016;138:2428-38.

13. Mezei AK, Armstrong HL, Pedersen HN, Campos NG, Mitchell SM, Sekikubo M, et al. Cost-effectiveness of cervical cancer screening methods in low-and middle-income countries: a systematic review. Int J Cancer. 2017;141:437-46.

14. Yunes-Diaz E, Ruiz PA, Lazcano-Ponce E. Assessment of the validity and reproducibility of the pap smear in Mexico: necessity of a paradigm shift. Arch Med Res. 2015;46:310-6.

15. Medina-Villaseñor EA, Oliver-Parra PA, Neyra-Ortiz E, PérezCastro JA, Sánchez-Orozco JR, Contreras-González N. Neoplasia intraepitelial cervical, análisis de las características clínicopatológicas. Gac Mex Oncol. 2014;13:12-25.

16. Gage JC, Hanson VW, Abbey K, Dippery S, Gardner S, Kubota J, et al. Number of cervical biopsies and sensitivity of colposcopy. Obstet Gynecol. 2006;108:264-72.

17. Ibanez R, Autonell J, Sarda M, Crespo N, Pique P, Pascual A, et al. Protecting the underscreened women in developed countries: the value of HPV test. BMC Cancer. 2014:14:574.

18. Wright TC, Schiffman M, Solomon D, Cox JT, Garcia F, Goldie S, et al. Interim guidance for the use of human papillomavirus DNA testing as an adjunct to cervical cytology for screening. Obstet Gynecol. 2004;103:304-9.

19. Huh WK, Ault KA, Chelmow D, Davey DD, Goulart RA, Garcia FA, et al. Use of primary high-risk human papillomavirus testing for cervical cancer screening: interim clinical guidance. Gynecol Oncol. 2015;136:178-82.

20. Aguilar-Lemarroy A, Vallejo-Ruiz V, Cortes-Gutierrez El, Salgado-Bernabe ME, Ramos-Gonzalez NP, Ortega-Cervantes L, et al. Human papillomavirus infections in Mexican women with normal cytology, precancerous lesions, and cervical cancer: type-specific prevalence and HPV coinfections. J Med Virol. 2015:87:871-84

21. Lazcano-Ponce E, Lorincz AT, Salmeron J, Fernandez I, Cruz A, Hernandez $\mathrm{P}$, et al. A pilot study of HPV DNA and cytology testing in 50,159 women in the routine Mexican social security program. Cancer Causes Control. 2010;21:1693-700.

22. Illades-Aguiar B, Alarcon-Romero LC, Antonio-Vejar V, ZamudioLopez N, Sales-Linares N, Flores-Alfaro E, et al. Prevalence and distribution of human papillomavirus types in cervical cancer, squamous intraepithelial lesions, and with no intraepithelial lesions in women from Southern Mexico. Gynecol Oncol. 2010; 117:291-6

23. Salcedo M, Pina-Sanchez P, Vallejo-Ruiz V, Monroy-Garcia A, Aguilar-Lemarroy A, Cortes-Gutierrez El, et al. Human papillomavirus genotypes among females in Mexico: a study from the Mexican institute for social security. Asian Pac J Cancer Prev. 2014; 15:10061-6.

24. Bruni L, Barrionuevo-Rosas L, Albero G, Serrano B, Mena M, Gómez D, et al. ICO/IARC Information Centre on HPV and Cancer (HPV Information Centre). Human Papillomavirus and Related Diseases in Mexico, Summary Report; 2019. Available from: https://www.hpvcentre.net/statistics/reports/MEX. pdf?t=1588908238114. [Last accessed on 2019 May 13].
25. Guan P, Howell-Jones R, Li N, Bruni L, de Sanjose S, Franceschi $S$, et al. Human papillomavirus types in 115,789 HPV-positive women: a meta-analysis from cervical infection to cancer. Int Cancer. 2012:131:2349-59.

26. Schiffman M, de Sanjose S. False positive cervical HPV screening test results. Papillomavirus Res. 2019;7:184-7.

27. Ferlay J, Ervik M, Lam F, Colombet M, Mery L, Piñeros M, et al. Global Cancer Observatory: cancer Today. Lyon, France: International Agency for Research on Cancer; 2018. Available from: https://www.gco.iarc.fr/today. [Last accessed On 2019 May 13].

28. Morris BJ. The advent of human papillomavirus detection for cervical screening. Curr Opin Obstet Gynecol. 2019;31: 333-9.

29. Committee on Practice Bulletins-Gynecology. Practice bulletin No. 168: cervical cancer screening and prevention. Obstet Gynecol. 2016;128:e111-30

30. Davey DD, Goulart R, Nayar R. 2013 statement on human papillomavirus DNA test utilization. Am J Clin Pathol. 2014; 141:459-61

31. Ye J, Cheng B, Cheng YF, Yao YL, Xie X, Lu WG, et al. Prognostic value of human papillomavirus $16 / 18$ genotyping in low-grade cervical lesions preceded by mildly abnormal cytology. J Zhejiang Univ Sci B. 2017;18:249-55.

32. Gayet C, Gutiérrez JP. Calendario de inicio sexual en México. Comparación entre encuestas nacionales y tendencias en el tiempo. Salud Publica Mex. 2014;56:638-47

33. Crosbie EJ, Einstein MH, Franceschi S, Kitchener HC. Human papillomavirus and cervical cancer. Lancet. 2013;382:889-99.

34. Ronco G, Rossi PG. Role of HPV DNA testing in modern gynaecological practice. Best Pract Res Clin Obstet Gynaecol. 2018; 47:107-18.

35. Secretaría de Salud. Proyecto de Modificación a la Norma Oficial Mexicana NOM-014-SSA2-1994, Para La Prevención, Detección, Diagnóstico, Tratamiento, Control y Vigilancia Espidemiológica del Cáncer Cervico uterino. Norway: DOF; 2006. Available from: https://www.dof.gob.mx.

36. Allen-Leigh B, Uribe-Zuniga $P$, Leon-Maldonado L, Brown BJ, Lorincz A, Salmeron J, et al. Barriers to HPV self-sampling and cytology among low-income indigenous women in rural areas of a middle-income setting: a qualitative study. BMC Cancer. 2017; 17:734.

37. Luhn P, Wentzensen N. HPV-based tests for cervical cancer screening and management of cervical disease. Curr Obstet Gynecol Rep. 2013;2:76-85

38. Katki HA, Kinney WK, Fetterman B, Lorey T, Poitras NE, Cheung $L$, et al. Cervical cancer risk for women undergoing concurrent testing for human papillomavirus and cervical cytology: a population-based study in routine clinical practice. Lancet Oncol. 2011;12:663-72

39. Sahasrabuddhe VV, Luhn P, Wentzensen N. Human papillomavirus and cervical cancer: biomarkers for improved prevention efforts. Future Microbiol. 2011;6:1083-98.

40. Schiffman M, Glass AG, Wentzensen N, Rush BB, Castle PE, Scott $\mathrm{DR}$, et al. A long-term prospective study of type-specific human papillomavirus infection and risk of cervical neoplasia amons 20,000 women in the Portland kaiser cohort study. Cancer Epidemiol Biomarkers Prev. 2011;20:1398-409.

41. Castle PE, Stoler MH, Wright TC, Sharma A, Wright TL, Behrens CM. Performance of carcinogenic human papillomavirus (HPV) testing and HPV16 or HPV18 genotyping for cervical cancer screening of women aged 25 years and older: a subanalysis of the Athena study. Lancet Oncol. 2011:12:880-90.

42. Kleter B, van Doorn LJ, Schrauwen L, Molijn A, Sastrowijoto S, ter Schegget J, et al. Development and clinical evaluation of a highly sensitive PCR-reverse hybridization line probe assay for detection and identification of anogenital human papillomavirus. J Clin Microbiol. 1999;37:2508-17.

43. Rossi PG, Benevolo M, Vocaturo A, Caraceni D, Ciccocioppo L, Frega A, et al. Prognostic value of HPV E6/E7 mRNA assay in women with negative colposcopy or CIN1 histology result: a follow-up study. PLoS One. 2013;8:e57600.

44. Yang L, Zhu Y, Bai Y, Zhang X, Ren C. The clinical application of HPV E6/E7 mRNA testing in triaging women with atypical squamous cells of undetermined significance or low-grade squamous intra-epithelial lesion pap smear: a meta-analysis. J Cancer Res Ther. 2017:13:613-20.

45. Ge Y, Christensen P, Luna E, Armylagos D, Schwartz MR, Mody DR. Performance of aptima and cobas HPV testing platforms in detecting high-grade cervical dysplasia and cancer. Cancer $\mathrm{Cy}$ topathol. 2017:125:652-7. 
46. Corden SA, Sant-Cassia LJ, Easton AJ, Morris AG. The integration of HPV-18 DNA in cervical carcinoma. Mol Pathol. 1999; 52:275-82.

47. Ibeanu OA. Molecular pathogenesis of cervical cancer. Cancer Biol Ther. 2011;11:295-306

48. Wentzensen N, Schwartz L, Zuna RE, Smith K, Mathews C, Gold $\mathrm{MA}$, et al. Performance of p16/Ki-67 immunostaining to detect cervical cancer precursors in a colposcopy referral population. Clin Cancer Res. 2012;18:4154-62.

49. Chauhan R, Verma N, Sharma S, Bhargava R, Singh P. Role of apoptotic index, mitotic index and MIB-1 antibody expression as biomarkers in preneoplastic and neoplastic lesions of uterine cervix. Int J Res Med Sci. 2016;4:2093-100.

50. Chen W, Tu L. Expression and clinical significance of MCM5 and P16 in hyperplastic disease of the cervix. Oncol Transl Med. 2018;4:13-7.

51. Matos LL, Trufelli DC, de Matos MG, Pinhal MA. Immunohistochemistry as an important tool in biomarkers detection and clinical practice. Biomark Insights. 2010;5:9-20.

52. Del Pino M, Svanholm-Barrie C, Torne A, Marimon L, Gaber J, Sagasta A, et al. mRNA biomarker detection in liquid-based cytology: a new approach in the prevention of cervical cancer. Mod Pathol. 2015;28:312-20.

53. Esteller M. Epigenetics in cancer. N Engl J Med. 2008;358: 1148-59.

54. van Leeuwen RW, Ostrbenk A, Poljak M, van der Zee AG, Schuuring $E$, Wisman GB. DNA methylation markers as a triage test for identification of cervical lesions in a high risk human papillomavirus positive screening cohort. Int J Cancer. 2019. 144:746-54.

55. Lorincz AT, Brentnall AR, Scibior-Bentkowska D, Reuter C, Banwait R, Cadman L, et al. Validation of a DNA methylation HPV triage classifier in a screening sample. Int J Cancer. 2016; 138:2745-51.

56. Clarke MA, Luhn P, Gage JC, Bodelon C, Dunn ST, Walker J, et al. Discovery and validation of candidate host DNA methylation markers for detection of cervical precancer and cancer. Int J Cancer. 2017;141:701-10

57. Zhao Q, He Y, Wang XL, Zhang YX, Wu YM. Differentially expressed proteins among normal cervix, cervical intraepithelial neoplasia and cervical squamous cell carcinoma. Clin Transl Oncol. 2015;17:620-31.

58. Cortez MA, Ivan C, Zhou P, Wu X, Ivan M, Calin GA. microRNAs in cancer: from bench to bedside. Adv Cancer Res. 2010; 108:113-57

59. Pedroza-Torres A, Fernandez-Retana J, Peralta-Zaragoza O, Jacobo-Herrera N, Cantu de Leon D, Cerna-Cortes JF, et al. A microRNA expression signature for clinical response in locally advanced cervical cancer. Gynecol Oncol. 2016;142:557-65.
60. Inan H, Wang S, Inci F, Baday M, Zangar R, Kesiraju S, et al Isolation, detection, and quantification of cancer biomarkers in HPV-associated malignancies. Sci Rep. 2017;7:3322.

61. Xu Y, Jin Y, Liu L, Zhang X, Chen Y, Wei J. Study of circulating IgG antibodies to peptide antigens derived from BIRC5 and MYC in cervical cancer. FEBS Open Bio. 2015;5:198-201.

62. Huangfu M, Liu L, Xu S, Li S, Jiang K, Sun B, et al. Detecting of p16 autoantibody as a potential early diagnostic serum biomarker in patients with cervical cancer. Clin Lab. 2016;62: 1117-20.

63. Xu S, Huangfu M, Jia X, Song X, Sun B, Lee KH, et al. FOXP3 autoantibody as a potential early prognostic serum biomarker in patients with cervical cancer. Int J Clin Oncol. 2015; 20:982-8.

64. Cuzick J, Cadman L, Mesher D, Austin J, Ashdown-Barr L, Ho $L$, et al. Comparing the performance of six human papillomavirus tests in a screening population. $\mathrm{Br}$ J Cancer. 2013 108:908-13.

65. Heideman DA, Hesselink AT, Berkhof J, van Kemenade F, Melchers WJ, Daalmeijer NF, et al. Clinical validation of the cobas 4800 HPV test for cervical screening purposes. J Clin Microbiol. 2011:49.3983-5.

66. Bottari F, Sideri M, Gulmini C, Igidbashian S, Tricca A, Casadio C, et al. Comparison of onclarity human papillomavirus (HPV) assay with hybrid capture II HPV DNA assay for detection of cervical intraepithelial neoplasia grade 2 and 3 lesions. J Clin Microbiol. 2015;53:2109-14.

67. Ejegod D, Bottari F, Pedersen $H$, Sandri MT, Bonde J. The BD Onclarity HPV assay on samples collected in surepath medium meets the international guidelines for human papillomavirus test requirements for cervical screening. J Clin Microbiol. 2016; 54:2267-72.

68. lacobellis M, Violante C, Notarachille G, Simone A, Scarfi R, Giuffre G. Clinical validation of Realquality RQ-HPV Screen according to the international guidelines for human papillomavirus DNA test requirements for cervical screening. Virol J. 2018;15:48.

69. Jung S, Lee B, Lee KN, Kim Y, Oh EJ. Clinical validation of anyplex II HPV HR detection test for cervical cancer screening in Korea. Arch Pathol Lab Med. 2016;140:276-80.

70. Boers A, Wang R, Slagter-Menkema L, van Hemel BM, Ghyssaert $H$, van der Zee AG, et al. Clinical validation of the cervista HPV HR test according to the international guidelines for human papillomavirus test requirements for cervical cancer screening. J Clin Microbiol. 2014;52:4391-3.

71. Hesselink AT, Meijer CJ, Poljak M, Berkhof J, van Kemenade FJ, van der Salm ML, et al. Clinical validation of the abbott realtime high risk HPV assay according to the guidelines for human papillomavirus DNA test requirements for cervical screening. J Clin Microbiol. 2013;51:2409-10. 